STRUCTURAL BIOLOGY

ISSN 2059-7983

Received 19 October 2017

Accepted 5 December 2017

Edited by A. Berghuis, McGill University, Canada

Keywords: MamC; magnetosome;

biomineralization; protein-mineral interaction.

PDB references: unstructured MamC magnetitebinding protein located between two helices,

$5 \mathrm{~mm} 3$; a MamC-MIC insertion in an MBP

scaffold at position Lys170, 6eqz

Supporting information: this article has supporting information at journals.iucr.org/d

\section{The importance of the helical structure of a MamC-derived magnetite-interacting peptide for its function in magnetite formation}

\author{
Hila Nudelman, ${ }^{\mathrm{a}}$ Teresa Perez Gonzalez, ${ }^{\mathrm{b}}$ Sofiya Kolushiva, ${ }^{\mathrm{c}}$ Marc Widdrat, ${ }^{\mathrm{d}}$ \\ Victoria Reichel, ${ }^{\mathrm{d}}$ Ana Peigneux, ${ }^{\mathrm{b}}$ Geula Davidov, ${ }^{\mathrm{a}}$ Ronit Bitton, ${ }^{\mathrm{c}, \mathrm{e}}$ Damien Faivre, ${ }^{\mathrm{d}}$ \\ Concepcion Jimenez-Lopez ${ }^{\mathrm{b}}$ and Raz Zarivach ${ }^{\mathrm{a}, \mathrm{c} *}$
}

\begin{abstract}
${ }^{\mathbf{a}}$ Department of Life Sciences and the National Institute for Biotechnology in the Negev, Ben-Gurion University of the Negev, Beer Sheva, Israel, 'b Departamento de Microbiologia, Campus de Fuentenueva, Universidad de Granada, 18071 Granada, Spain, ' Ilse Katz Institute for Nanoscale Science and Technology, Ben-Gurion University of the Negev, Beer Sheva, Israel, ${ }^{\mathbf{d}}$ Department of Biomaterials, Max Planck Institute of Colloids and Interfaces, Potsdam, Germany, and ${ }^{\mathbf{e}}$ Department of Chemical Engineering, Ben-Gurion University of the Negev, Beer Sheva, Israel. *Correspondence e-mail: zarivach@bgu.ac.il
\end{abstract}

Biomineralization is the process of mineral formation by organisms and involves the uptake of ions from the environment in order to produce minerals, with the process generally being mediated by proteins. Most proteins that are involved in mineral interactions are predicted to contain disordered regions containing large numbers of negatively charged amino acids. Magnetotactic bacteria, which are used as a model system for iron biomineralization, are Gram-negative bacteria that can navigate through geomagnetic fields using a specific organelle, the magnetosome. Each organelle comprises a membrane-enveloped magnetic nanoparticle, magnetite, the formation of which is controlled by a specific set of proteins. One of the most abundant of these proteins is MamC, a small magnetosome-associated integral membrane protein that contains two transmembrane $\alpha$-helices connected by an $\sim 21$-amino-acid peptide. In vitro studies of this MamC peptide showed that it forms a helical structure that can interact with the magnetite surface and affect the size and shape of the growing crystal. Our results show that a disordered structure of the MamC magnetite-interacting component (MamC-MIC) abolishes its interaction with magnetite particles. Moreover, the size and shape of magnetite crystals grown in in vitro magnetiteprecipitation experiments in the presence of this disordered peptide were different from the traits of crystals grown in the presence of other peptides or in the presence of the helical MIC. It is suggested that the helical structure of the MamC-MIC is important for its function during magnetite formation.

\section{Introduction}

Biomineralization is the most common process of mineral deposition by living organisms and can be found in all kingdoms of life. This process allows an organism to take up ions from the environment and incorporate them into functional structures that are useful for mechanical support (skeletons) and protection (shells) and that allow magnetotaxis (magnetosomes) (Mann, 2001; Lowenstam \& Weiner, 1989; Dove, 2010).

The formation of biominerals is highly regulated by macromolecules, mostly proteins, which are involved in the nucleation, growth, morphology and assembly of the inorganic matrix (Lowenstam \& Weiner, 1989). Many of the proteins involved in biomineralization processes partially or fully lack three-dimensional structure and instead are usually considered to be intrinsically disordered proteins (IDPs) or to 
Table 1

Macromolecule-production information.

Source organism
Cloning vector
Expression vector
Expression host
Complete amino-acid sequence
$\quad$ of the MC R354 construct

Complete amino-acid sequence of the MC K170 construct of the MC K313 construct
Complete amino-acid sequence

\section{M. magneticum AMB-1 \\ pET-28a $\dagger$ \\ pET-28a \\ E. coli Rosetta}

MGSSHHHHHHS SGLVPRGSHMKIEEGKLVI WINGDKGYNGLAEVGKKFEKDTGIKVTV EHPDKLEEKFPQVAATGDGPDI I FWAHD RFGGYAQSGLLAEITPDKAFQDKLYPFT WDAVRYNGKLIAYPIAVEALSLIYNKDI LPNPPKTWEEI PALDKELKAKGKSALME NLQEPYFTWPLIAADGGYAFKYENGKYD IKDVGVDNAGAKAGLTFLVDLIKNKHMN ADTDYSIAEAAFNKGETAMTINGPWAWS NIDTSKVNYGVTVLPTEKGQPSKPFVGV LSAGINAAS PNKELAKEFLENYLLTDEG LEAVNKDKPLGAVALKSYEEELAKDPRI AATMENAQKGE IMI PNI PQMSAFWYAVR TAVINAASGRLKEKRITNTEAAIDTGKE TVGQTVDEALKDAQTNSSS

MGSSHHHHHHS SGLVPRGSHMKIEEGKLVI WINGDKGYNGLAEVGKKFEKDTGIKVTV EHPDKLEEKFPQVAATGDGPDI I FWAHD RFGGYAQSGLLAEITPDKAFQDKLYPET WDAVRYNGKLIAYPIAVEALSLIYNKDI LPNPPKTWEEIPALDKELKAKGKSALMF NLQEPYFTWPLIAADGGYAFLKEKRITN TEAAIDTGKETVGVGVDNAGAKAGLTFI VDLIKNKHMNADTDYSIAEAAFNKGETA MTINGPWAWSNIDTSKVNYGVTVLPTEK GQPSKPFVGVLSAGINAAS PNKELAKEF LENYLLTDEGLEAVNKDKPLGAVALKSY EEELAKDPRIAATMENAQKGE IMPNIPQ MSAFWYAVRTAVINAASGRQTVDEALKD AQTNSSS

MGSSHHHHHHSSGLVPRGSHMKIEEGKLVI WINGDKGYNGLAEVGKKFEKDTGIKVTV EHPDKLEEKFPQVAATGDGPDI IFWAHD RFGGYAQSGLLAEITPDKAFQDKLYPFT WDAVRYNGKLIAYPIAVEALS LIYNKDI LPNPPKTWEEIPALDKELKAKGKSALMF NLQEPYFTWPLIAADGGYAFKYENGKYD IKDVGVDNAGAKAGLTFLVDLIKNKHMN ADTDYSIAEAAFNKGETAMTINGPWAWS NIDTSKVNYGVTVLPTFKGQPSKPFVGV LSAGINAAS PNKELAKEFLENYLLTDEG LEAVNKDKPLGAVALKSYEEELAKLKEK RITNTEAAIDTGKETVGDPRIAATMENA QKGEIMPNI PQMSAFWYAVRTAVINAAS GRQTVDEALKDAQTNSSS

$\dagger$ All plasmids were purchased from Biomatik Corporation, Ontario, Canada.

contain intrinsically disordered regions (IDRs) (Wald et al., 2013). IDPs are rich in polar and charged residues and contain few hydrophobic amino acids, which are generally responsible for stable structural folds. In addition to contributing to biomineralization, unstructured proteins are also found in regulatory and signalling pathways, such as in transmembrane receptors, intracellular scaffolds, chaperones and transcription factors (Wojtas et al., 2012).

Proteins that participate in the biomineralization process generally inhibit or regulate mineral formation by controlling the direction and extension of crystal growth (Addadi \& Weiner, 1992). For instance, osteopontin, one of the well studied biomineralizing proteins with an unfolded structure, regulates calcium crystallization in both bone and teeth (Fisher et al., 2001). Its flexible structure enables osteopontin to bind to other proteins or to mineral phases (Fisher et al., 2001).

To better understand the relationship between the structure of a protein and its mineral-interacting properties, we used a peptide derived from MamC, a protein associated with the magnetosome membrane in magnetotactic bacteria (MTB). MTB are able to navigate the Earth's magnetic field via the formation of magnetic minerals from iron ions within a specialized organelle, the magnetosome. The magnetosome is composed of magnetic (magnetite or greigite) nanoparticles surrounded by a lipid bilayer membrane. Each bacterial cell contains one or several magnetosome chain(s) that align(s) along the cell axis so as to allow a sufficient magnetic dipole for geomagnetic field alignment. Diversity in the size and shape of these magnetic nanoparticles is regulated by magnetosome-associated proteins (MAPs). Mms6 is the most abundant and most studied MAP and, using mms6-knockout mutants, has been shown to be involved in magnetite formation in the magnetosome (Raschdorf et al., 2017). The deletion or mutation of mms 6 caused defects in the size and shape of magnetite particles (Amemiya et al., 2007; Tanaka et al., 2011; Yamagishi et al., 2016). In vitro studies also showed that Mms6 affects magnetite particle size and shape during iron precipitation and that the $22 \mathrm{C}$-terminal residues are essential for function (Kashyap et al., 2014; Rawlings et al., 2016; Yamagishi et al., 2016).

Although Mms6 is important for magnetite formation, MamC (Mms13) is the second most abundant MAP in the magnetosome membrane (MM) and is highly conserved in magnetotactic Alphaproteobacteria (Grünberg et al., 2004; Jogler \& Schüler, 2009; Raschdorf et al., 2017). MamC from Magnetospirillum magneticum AMB-1 is a small integral membrane protein $(12.4 \mathrm{kDa})$ with two transmembrane helices connected by a small peptide of 21 residues in length (MamC magnetite-interacting component; MamC-MIC) that is directed into the magnetosome lumen. In in vitro experiments, MamC, expressed as a recombinant protein, was shown to affect the size of magnetite crystals, with larger crystals growing in the presence of the protein compared with those grown in the absence of MamC (Valverde-Tercedor et al., 2015; Nudelman et al., 2016).

To better understand the interaction of MamC-MIC with magnetite, we previously created a chimera of maltose-binding protein (MBP) with MamC-MIC (MBP-MamC-MIC). These studies established that the MIC adopts an $\alpha$-helical structure that can interact with magnetite and affect its size and shape during in vitro iron precipitation (Nudelman et al., 2016). In the electron-density map of the MamC-MIC structure, we could detect only 17 amino acids of the 21 residues comprising the peptide, yet we showed that the peptide adopts a helical conformation. The MIC $\alpha$-helix contains two electrostatic charged areas on its surface that are conserved in all MamCMIC homologues (Nudelman et al., 2016). It was further shown that the MamC-MIC C-terminus presents a negatively charged electrostatic surface, which is suspected to bind to the magnetite surface and control its size and shape. This interaction is most likely to take place via two negatively charged 
Table 2

Crystallization.

\begin{tabular}{|c|c|c|}
\hline & MC R354 & MC K170 \\
\hline Plate type & Cryschem S small 24-well plate & MRC 96-well plate \\
\hline Temperature $(\mathrm{K})$ & 293.15 & 293.15 \\
\hline Protein concentration $\left(\mathrm{mg} \mathrm{ml}^{-1}\right)$ & 11.5 & 20 \\
\hline Buffer composition of protein solution & $20 \mathrm{~m} M$ Tris $\mathrm{pH} 8,200 \mathrm{~m} M \mathrm{NaCl}$ & $20 \mathrm{~m} M$ Tris $\mathrm{pH} 8,200 \mathrm{~m} M \mathrm{NaCl}$ \\
\hline Composition of reservoir solution & 1.4 $M$ trisodium citrate, $0.1 M$ HEPES & $1.86 M$ triammonium citrate \\
\hline Volume and ratio of drop & $1 \mu \mathrm{l}, 1: 1$ & $0.6 \mu \mathrm{l}, 1: 1$ \\
\hline Volume of reservoir & $0.5 \mathrm{ml}$ & $80 \mu \mathrm{l}$ \\
\hline
\end{tabular}

residues, Glu66 and Asp70, located near the C-terminus of the MIC and which contribute to the negatively charged surface. To further mimic the position of the MIC between the two MamC integral membrane $\alpha$-helices, in the present work the MamC-MIC was inserted between two helices in Escherichia coli maltose-binding protein (MBP), based on the MBP structure. This yielded several versions of the MBP-MamCMIC chimera, with three different MamC-MIC constructs being inserted at three different positions in the MBP sequence. In the first MamC-MIC was introduced between the last two helices of the MBP scaffold (between Arg354 and Gln355; named MC R354), while in the other two MamC-MIC was positioned in the middle of the MBP structure, and these were named according to their positions as MC K170 and MC $\mathrm{K} 313$. We used isothermal titration calorimetry (ITC), in vitro iron precipitation, small-angle X-ray scattering (SAXS) and $\mathrm{X}$-ray crystallography measurements to further characterize and define the link between structured/unstructured folds and MamC-MIC function.

\section{Materials and methods}

\subsection{Protein cloning}

To generate MC R354, a 21-amino-acid peptide derived from the M. magneticum strain AMB-1 mamC gene (MamCMIC; Leu57-Gly77) was cloned into plasmid pET-28a encoding $E$. coli $\mathrm{MBP}$ between the last two helices of the MBP C-terminal region (Arg354-Gln355). To generate MC K170 and MC K313, the 21-amino-acid MamC-MIC (Leu57-Gly77) was inserted between MBP residues Lys170 and Asp180 or Lys313 and Lys314, respectively. All constructs were cloned into the pET-28a vector. All constructs were purchased from Biomatik, Cambridge, Ontario, Canada (Table 1). MBPMamC-MIC and MBP-Mms6-MIC have been described by Nudelman et al. (2016).

\subsection{Protein expression}

Competent E. coli Rosetta cells were transformed with one of the plasmids described above and grown in $121 \mathrm{LB}$ medium with $50 \mathrm{mg} \mathrm{ml}^{-1}$ kanamycin and $30 \mathrm{mg} \mathrm{ml}^{-1}$ chloramphenicol at $37^{\circ} \mathrm{C}$. Protein production was induced with autoinduction medium (Formedium, Hunstanton, England); after $8 \mathrm{~h}$ at $37^{\circ} \mathrm{C}$ the protein was expressed overnight at $27^{\circ} \mathrm{C}$. The cells were collected by centrifugation for $8 \min \left(7400 \mathrm{~g}\right.$ at $\left.4^{\circ} \mathrm{C}\right)$ and frozen at $-80^{\circ} \mathrm{C}$ until use.

\subsection{Protein purification}

The cells were thawed and resuspended in binding buffer $A$ (20 mM Tris- $\mathrm{HCl}$ pH 8, $200 \mathrm{~m} M \mathrm{NaCl}, 1 \mathrm{~m} M$ EDTA). Protease-inhibitor cocktail $(100 \mu M$ phenylmethylsulfonyl fluoride, $1.2 \mu \mathrm{g} \mathrm{ml}^{-1}$ leupeptin and $1 \mu M$ pepstatin A) and DNase $\left(10 \mathrm{mg} \mathrm{ml}^{-1}\right)$ were added after cell resuspension. The cells were lysed by two rounds of disruption using a French press apparatus at $172 \mathrm{MPa}$ (Thermo, Waltham, Massachusetts, USA). The crude lysate was then centrifuged (31 000 $g$ at $4{ }^{\circ} \mathrm{C}$ ) for $40 \mathrm{~min}$. The supernatant was loaded onto a preequilibrated amylose resin column followed by washing with five column volumes of binding buffer $A$. The protein was eluted with elution buffer $B(20 \mathrm{~m} M$ Tris- $\mathrm{HCl} \mathrm{pH} \mathrm{8,} 200 \mathrm{~m} M$ $\mathrm{NaCl}, 10 \mathrm{~m} M$ maltose, $5 \mathrm{~m} M$ imidazole). The eluted fractions were loaded onto a homemade gravity Ni-NTA column [4 ml bed volume, $2.5 \mathrm{~cm}$ diameter; Econo-Column Chromatography Column (Bio-Rad) containing Ni-NTA His-Bind Resin, Lot M0063428 (Novagen)] pre-equilibrated with buffer $B$. The protein was washed with buffers $C, D$ and $E$ (buffer $C$, $20 \mathrm{~m} M$ Tris-HCl pH 8, $1 M \mathrm{NaCl}, 20 \mathrm{~m} M$ imidazole; buffer $D$, $20 \mathrm{~m} M$ Tris- $\mathrm{HCl} \mathrm{pH} 8,500 \mathrm{~m} M \mathrm{NaCl}, 30 \mathrm{~m} M$ imidazole; buffer $E, 20 \mathrm{~m} M$ Tris- $\mathrm{HCl} \mathrm{pH} 8,200 \mathrm{mM} \mathrm{NaCl}, 40 \mathrm{~m} M$ imidazole). The protein was eluted with buffer $F(20 \mathrm{~m} M$ Tris$\mathrm{HCl} \mathrm{pH} 8,200 \mathrm{~m} M \mathrm{NaCl}, 500 \mathrm{~m} M$ imidazole) and concentrated. The concentrated protein sample was loaded onto a size-exclusion column (Superdex 75 26/60, GE Healthcare Life Sciences) and eluted at a size that correlated to a monomer $(44 \mathrm{kDa})$. All fractions were collected, concentrated, flash-cooled in liquid nitrogen and stored at $-80^{\circ} \mathrm{C}$. All purification steps were analyzed by $12.5 \%$ SDS-PAGE.

\subsection{Crystal screening for MC K354 and MC K170}

A 96-well sitting-drop plate was set up using the Index kit (Hampton Research, Aliso Viejo, California, USA) for MC R354 and MC K170. Each well in the plate contained two protein drops corresponding to MC R354 with or without a polyhistidine tag at concentrations of 14 and $11.4 \mathrm{mg} \mathrm{ml}^{-1}$, respectively. For MC K170, each well contained different protein concentrations: 7.5 and $15 \mathrm{mg} \mathrm{ml}^{-1}$. The plates were stored at $20^{\circ} \mathrm{C}$ in an automated imaging system (Rock Imager, Formulatrix, Bedford, Massachusetts, USA). Positive hits were observed for MC R354 in a single condition, namely $1.4 \mathrm{M}$ trisodium citrate, for the untagged construct and $0.1 \mathrm{M}$ HEPES $\mathrm{pH} 7.5$ for the polyhistidine-tagged construct. For MC K170, positive hits were observed in one condition, namely 
Table 3

Data collection and processing.

Values in parentheses are for the outer shell.

\begin{tabular}{lll}
\hline & $\begin{array}{l}\text { MC R354 } \\
\text { (PDB entry 5mm3) }\end{array}$ & $\begin{array}{l}\text { MC K170 } \\
(\text { PDB entry 6eqz) }\end{array}$ \\
\hline Diffraction source & ID14-4, ESRF & ID29, ESRF \\
Wavelength $(\AA)$ & 0.939 & 0.976 \\
Temperature $(\mathrm{K})$ & 100 & 100 \\
Detector & ADSC Q315 & Pilatus 6MF \\
Crystal-to-detector distance (mm) & 303.4 & 391.26 \\
Rotation range per image $\left({ }^{\circ}\right)$ & 0.2 & 0.1 \\
Total rotation range $\left({ }^{\circ}\right)$ & 69 & 130 \\
Exposure time per image $(\mathrm{s})$ & 0.1 & 0.037 \\
Space group & $P 4_{1} 2_{1} 2$ & $P 222$ \\
$a, b, c(\AA)$ & $115,115,117$ & $110.6,113.8,115.5$ \\
$\alpha, \beta, \gamma\left({ }^{\circ}\right)$ & $90,90,90$ & $90,90,90$ \\
Mosaicity $\left({ }^{\circ}\right)$ & 0.599 & 0.170 \\
Resolution range $(\AA)$ & $82.18-2.10$ & $46.70-2.29$ \\
Total No. of reflections & 116817 & 318921 \\
No. of unique reflections & 38573 & 65839 \\
Completeness $(\%)$ & $82.6(87.5)$ & $99.6(95.0)$ \\
Multiplicity & $3.0(2.9)$ & $4.8(4.7)$ \\
$\langle I / \sigma(I)\rangle$ & $23.3(4.56)$ & $5.5(0.8)$ \\
$R_{\text {r.i.m }}{ }^{\dagger}$ & $0.118(0.43)$ & $0.284(2.40)$ \\
CC $C_{1 / 2}$ Overall $B$ factor from & $0.955(0.947)$ & $0.977(0.310)$ \\
$\quad$ Wilson plot $\left(\AA^{2}\right)$ & 27.00 & 36.46 \\
\hline
\end{tabular}

$\dagger R_{\text {r.i.m. }}$ is the $R_{\text {merge }}$ value multiplied by the factor $[N /(N-1)]^{1 / 2}$, where $N$ is the data multiplicity.

Table 4

Structure solution and refinement.

Values in parentheses are for the outer shell.

\begin{tabular}{|c|c|c|}
\hline & $\begin{array}{l}\text { MC R354 } \\
\text { (PDB entry 5mm3) }\end{array}$ & $\begin{array}{l}\text { MC K170 } \\
\text { (PDB entry 6eqz) }\end{array}$ \\
\hline Resolution range $(\AA)$ & $47.57-2.10$ & $26.70-2.30$ \\
\hline Completeness (\%) & 82.50 & 99.19 \\
\hline$\sigma$ Cutoff & None & 1.33 \\
\hline \multicolumn{3}{|l|}{ No. of reflections } \\
\hline Working set & 36623 & 65508 \\
\hline Test set & 1920 & 3320 \\
\hline Final $R_{\text {cryst }}$ & 0.1844 & 0.2046 \\
\hline Final $R_{\text {free }}$ & 0.2278 & 0.2738 \\
\hline Cruickshank DPI & 0.205 & 0.410 \\
\hline \multicolumn{3}{|l|}{ No. of non-H atoms } \\
\hline Protein & $\begin{array}{l}\text { Chain } A, 2891 \\
\quad \text { chain } B, 2740\end{array}$ & $\begin{array}{l}\text { Chain } A, 2937 \text {; chain } B, 2907 ; \\
\quad \text { chain } D, 2948 ; \text { chain } G, 2907\end{array}$ \\
\hline Ligand & 46 & 92 \\
\hline Water & 293 & 288 \\
\hline Total & 5970 & 12079 \\
\hline \multicolumn{3}{|l|}{ R.m.s. deviations } \\
\hline Bonds $(\AA)$ & 0.0105 & 0.009 \\
\hline Angles $\left({ }^{\circ}\right)$ & 1.4179 & 1.193 \\
\hline \multicolumn{3}{|c|}{ Average $B$ factors $\left(\AA^{2}\right)$} \\
\hline Overall & 32.30 & 42.72 \\
\hline Protein & $\begin{array}{l}\text { Chain } A, 29.93 \\
\text { chain } B, 35.12\end{array}$ & $\begin{array}{l}\text { Chain } A, 42.18 \text {; chain } B, 38.88 ; \\
\quad \text { chain } D, 45.12 \text {; chain } G, 45.75\end{array}$ \\
\hline Ligand & 27.061 & $\begin{array}{l}\text { Chain } E, 32.70 \text {; chain } C, 30.82 \text {; } \\
\quad \text { chain } F, 37.31 \text {; chain } H, 32.57\end{array}$ \\
\hline Water & 30.26 & 34.90 \\
\hline \multicolumn{3}{|c|}{ Ramachandran plot } \\
\hline Most favoured (\%) & 97.20 & 97.67 \\
\hline Allowed (\%) & 2.66 & 2.13 \\
\hline Outliers (\%) & 0.14 & 0.20 \\
\hline
\end{tabular}

1.8 $M$ triammonium citrate. Optimization plates were set up around these crystallization conditions (Table 2).

\subsection{Structure determination}

A data set for MC R354 was collected using a single crystal on beamline BM14 at the European Synchrotron Radiation Facility (ESRF), Grenoble, France. The MC R354 data set was collected using a wavelength of $0.939 \AA$. 1000 images were collected with an oscillation range of $0.2^{\circ}$, an exposure time of $0.01 \mathrm{~s}$ per image and a crystal-to-detector distance of $303.4 \mathrm{~mm}$. The data were processed and scaled using the HKL-2000 program suite (Otwinowski \& Minor, 1997). Phases were obtained via molecular replacement with Phaser using the coordinates of MBP-MamC-MIC (PDB entry 5e7u; H. Nudelman \& R. Zarivach, unpublished work) followed by manual building cycles using Coot (Emsley \& Cowtan, 2004; McCoy et al., 2007). Structures were refined in REFMAC5 (Murshudov et al., 2011), while the final model was refined and built using the PDB_REDO server (Joosten et al., 2009).

For MC K170, a data set was collected using a single crystal on beamline ID29 at ESRF. The MC K170 data set was collected with a wavelength of $0.976 \AA$. 1300 images were collected with an oscillation of $0.1^{\circ}$, an exposure time of $0.037 \mathrm{~s}$ per image and a crystal-to-detector distance of $391.26 \mathrm{~nm}$. The data were processed and scaled using $X D S$ (Kabsch, 2010). Phases were obtained via molecular replacement with Phaser using the coordinates of MBP-MamC-MIC (PDB entry 5e7u) followed by manual building cycles using Coot (Emsley \& Cowtan, 2004; McCoy et al., 2007). The structure was refined in PHENIX (Zwart et al., 2008). Structural figures were prepared using PyMOL (DeLano, 2002). Data-collection and structure-refinement statistics are given in Tables 3 and 4 .

\subsection{Synthesis of magnetic nanoparticles for protein- interaction experiments}

Magnetite was synthesized by a modified co-precipitation method controlled by a titration system (Metrohm, 776 Dosimat and $719 \mathrm{~S}$ Titrino). Iron(II)/iron(III) chloride solution $\left(1 M ; 1: 2 \mathrm{Fe}^{2+}: \mathrm{Fe}^{3+}\right)$ was added at a rate of $1 \mu l \mathrm{~min}^{-1}$ to a total volume of $10 \mathrm{ml}$. The $\mathrm{pH}$ and temperature were kept constant (the $\mathrm{pH}$ was held at $11 \pm 0.4$ with $1 M \mathrm{NaOH}$ and the temperature was held at $25 \pm 0.1^{\circ} \mathrm{C}$ ) during an $8 \mathrm{~h}$ synthetic process. All solutions were degassed before use and the system was kept in a nitrogen atmosphere during synthesis. Magnetite size was determined by assessing synchrotron X-ray diffraction on the $\mu$-Spot beamline (BESSY II, Berlin) by Scherrer analysis of the (311) peak of magnetite (Baumgartner et al., 2013; Widdrat et al., 2014).

\subsection{ITC}

Interactions between MamC constructs and magnetite were investigated at a constant temperature by titrating the protein samples (in $20 \mathrm{~m} M$ Tris- $\mathrm{HCl} \mathrm{pH} 8,200 \mathrm{~m} M \mathrm{NaCl}$ ) into a solution containing magnetite in the sample cell of the calorimeter, since magnetite can clog the injection needle. The heat change was expressed as the electrical power $\left(\mathrm{J} \mathrm{s}^{-1}\right.$; Jelesarov \& Bosshard, 1999). As a control, each protein was also injected into a buffer without magnetite particles. All 
measurements were compared with a reference cell containing distilled deionized water. Owing to magnetite-particle agglomeration, the thermodynamic parameters could not be determined. Only interactions between proteins and magnetite particles were obtained. Therefore, each sample was measured three times to confirm the protein-magnetite interaction results.

\subsection{SAXS}

SAXS experiments were performed on the BM29 BioSAXS beamline at the ESRF. An energy level of $12.5 \mathrm{keV}$, corresponding to a wavelength of $0.998 \AA$, was selected. The scattering intensity was recorded using a Pilatus $1 \mathrm{M}$ detector in the $0.004<q<0.5 \AA^{-1}$ interval. Ten frames with $2 \mathrm{~s}$ exposure time were recorded for each sample. Measurements were performed in flow mode, with samples being pumped through the capillary at a constant flow rate. The dedicated beamline software $B s x C u B e$ and EDNA were used for data collection and preliminary processing. Further analyses and final plot preparations were performed using $A T S A S$ and IGOR v.6.3 (Franke et al., 2017). A theoretical $R_{\mathrm{g}}$ was calculated from the PDB file using CRYSOL.

\subsection{Free-drift biomineralization experiments}

Free-drift biomineralization experiments were performed following the procedures described in Valverde-Tercedor $e t$ al. (2015) and Nudelman et al. (2016). All reagents were purchased from Sigma-Aldrich. Briefly, deoxygenated solutions of $0.15 M \mathrm{NaHCO}_{3} / \mathrm{Na}_{2} \mathrm{CO}_{3}, 1 M \mathrm{FeCl}_{3}, 0.5 M \mathrm{Fe}\left(\mathrm{ClO}_{4}\right)_{2}$ and $5 \mathrm{M} \mathrm{NaOH}$ were prepared with deoxygenated Milli-Q water. Aliquots of the peptides used in the present study were bubbled with purified nitrogen for $10 \mathrm{~min}$ to remove residual $\mathrm{O}_{2}$ and placed inside a Coy chamber along with the water. Synthesis and material handling were carried out inside the anaerobic chamber $\left(\mathrm{O}_{2}\right.$ level of $\sim 40$ p.p.b. $)$ to avoid potential oxidation.

Inorganic magnetite was precipitated from solutions in freedrift experiments held at $25^{\circ} \mathrm{C}$ and $101.3 \mathrm{kPa}$ total pressure inside the Coy chamber filled with $4 \% \mathrm{H}_{2}$ in $\mathrm{N}_{2}$, following the protocol described by Perez-Gonzalez et al. (2011). Different volumes of the solutions listed above were mixed to prepare the precipitation solution to a final composition of $3.5 \mathrm{mM}$ $\mathrm{NaHCO}_{3} / \mathrm{Na}_{2} \mathrm{CO}_{3}, 5.56 \mathrm{~m} M \mathrm{FeCl}_{3}, 2.78 \mathrm{mM} \mathrm{Fe}\left(\mathrm{ClO}_{4}\right)_{2} \mathrm{pH}$ 9, which was achieved by the addition of $\mathrm{NaOH}$ solution.

Analysis of the effect of MC K354 on magnetite precipitation was carried out in the presence of the chimera at $10 \mu \mathrm{g} \mathrm{ml}^{-1}$. The reaction was allowed to proceed inside the anaerobic chamber for $30 \mathrm{~d}$, after which time the precipitated materials were harvested. The precipitated solids were concentrated in tubes with a magnet, while the supernatants, which were transparent and contained no visible solids, were discarded. The precipitates were washed with deoxygenated water. This washing procedure was repeated three times, after which the precipitate was collected, immediately freeze-dried (Flexi-Dry $\mu \mathrm{P}$ ) and stored inside the anaerobic chamber until analysis. Data from this study were compared with those reported by Nudelman et al. (2016), with the MBP-MamCMIC in the present study corresponding to MBP-long as described in the previous report.

\subsection{Transmission electron microscopy (TEM)}

The morphologies and sizes of the crystals collected above were studied by TEM using a Philips Model CM20 electron microscope equipped with an energy-dispersive X-ray spectrometer (EDAX). The synthesized magnetic powders were dehydrated with ethanol and embedded in Embed 812 resin. Ultrathin $(50-70 \mathrm{~nm})$ sections were prepared using a Reichert Ultracut S microtome (Leica Microsystems, Wetzlar, Germany). The sections were placed onto copper grids and carbon-coated using an Emitech Model K975X thermal evaporator (Fall River, Massachusetts, USA). Imaging and size-distribution analyses were performed on more than 600 nanoparticles in each experiment. Crystal sizes were measured manually using ImageJ v.1.47, while size-distribution curves were determined from these measurements using OriginPro v.9. Statistical calculations were performed using Statistica v.12 and Microsoft Excel.

\section{Results and discussion}

\subsection{Structural analysis}

MC R354 gave positive hits during our crystallographic trials, crystallizing as diamond-shaped crystals with two molecules in the asymmetric unit. The MC R354 crystal diffracted to $2.1 \AA$ resolution and its structure was determined via molecular replacement using the MBP-MamC-MIC structure (PDB entry 5e7u) followed by manual building. The structure of MC R354 revealed that only one chain in the asymmetric unit, chain $A$, contained sufficient electron density to allow structure determination of MamC-MIC. Only 17 amino acids of MamC-MIC were found in an unstructured conformation, while the last four residues and the following $\alpha$-helix in the MBP C-terminal region (Gln376-Ser391) were not observed (Figs. $1 a$ and $1 b$ ). In contrast to MC R354 chain $A$, we were able to resolve chain $B$ up to Ala352; this chain therefore lacks both the MamC loop and the MBP C-terminal region, probably owing to the high flexibility of MamC-MIC.

Structural overlap of the two MBP monomers in the asymmetric unit revealed substantial structural identity, supported by a root-mean-square deviation (r.m.s.d.) of $0.46 \AA$, indicating high similarity between these two MBP chains. In contrast, the overlap between helical MamC-MIC (PDB entry 5e7u) and the unstructured MamC-MIC moiety from MC R354 chain $A$ (PDB entry 5mm3) yielded a higher r.m.s.d. of $6.28 \AA$, reflecting large structural differences between the two (Figs. $1 c$ and $1 d$; Nudelman et al., 2016). The inability of MamC-MIC to form a helical structure in MC R354 could result from instability of the last 16 amino acids at the MBP C-terminus (Gln376-Ser391). Interruption of this $\mathrm{C}$-terminal helical structure is probably owing to the insertion of MamC-MIC.

In previous studies, MamC-MIC presented a helical structure when attached to the C-terminus of MBP. In the helical 
structure, Glu66 and Asp70 in MamC-MIC were responsible for the negatively charged surface, which was shown to be highly important for MamC-MIC function (Nudelman et al., 2016). Despite Glu66 and Asp70 being directed to the same side in MC R354, the electrostatic density map differed from that for the helical structure of MamC-MIC (Figs. $1 c$ and $1 d$ ). Moreover, in MC R354 the distance between Glu66 and Asp70 is $11.62 \AA$ (Fig. 1c), while in the helical MIC structure this distance is only $8 \AA$ (Fig. $1 d$ ), a value that fits the distance between two $\mathrm{Fe}$ atoms on the (111), (100), (311) and (110) magnetite faces (Nudelman et al., 2016; Lopez-Moreno et al., 2017). Although the distance between these amino acids in the MC R354 structure can change owing to the high flexibility of the MIC structure, the probability of the moiety forming a stable structure that is able to interact with the magnetite surface is low.

The finding that MamC-MIC is visible only in one chain in the asymmetric unit confirms its flexibility. The detection of the MIC is most likely to be a result of crystal contacts with specific MBP molecules that are ordered in the crystal. These molecules act as MamC-MIC docking sites and stabilize this entity as an unstructured fold (Fig. 1b). Similar to the limited viability of the C-terminal region of MamC-MIC in the helical MamC-MIC structure (PDB entry 5e7u), only 17 of the 21 amino acids in this moiety are detected. The absence of electron density for the last four MamC-MIC residues is related to their high flexibility, which prevents protein chain ordering.

To emphasize the disorder in the structure of the MC R354 C-terminal region, we performed SAXS experiments which allowed analysis of the protein envelope in solution. Fig. 2(a) shows the one-dimensional curves obtained for the different proteins (i.e. MBP, MBP-MamC-MIC and MC R354). In the cases of MamC-MIC and MC R354 the curve shapes indicate a protein in a monomeric state, while the MBP curve starts with a short sloping area that could indicate protein aggregation (Fig. 2a). According to the Kratky plots (Fig. 2b), the curves all present the same bell-like shape, which correlates with a globular protein. Furthermore, Guinier plots indicate that MC $\mathrm{R} 354$ has a higher radius of gyration $\left(R_{\mathrm{g}}\right)$ than MBP or MBPMamC-MIC. Ignoring the aggregation of MBP, the slope from the linear area of the curve (Fig. $2 c$ ) indicates a small $R_{\mathrm{g}}$ of

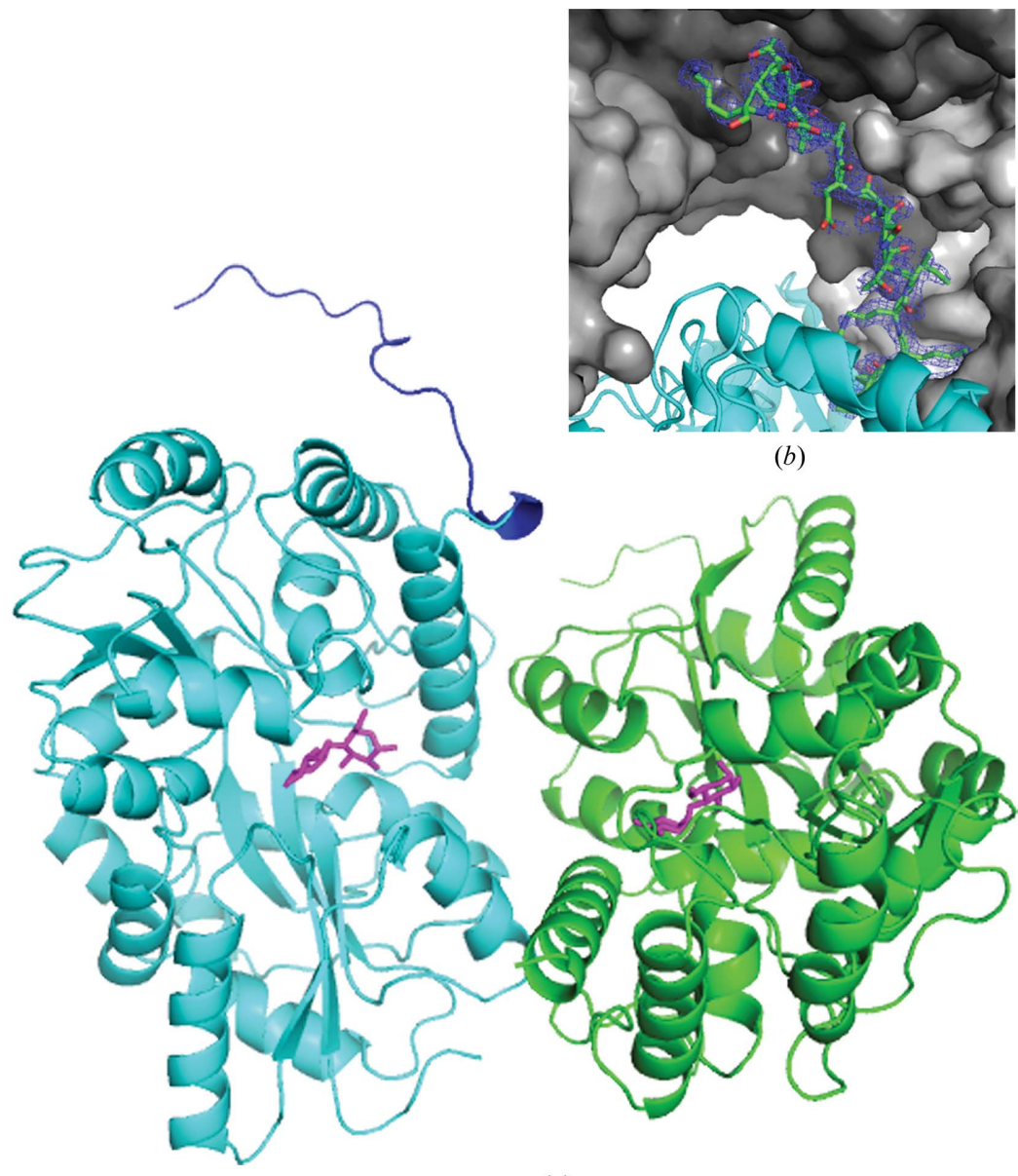

(a)
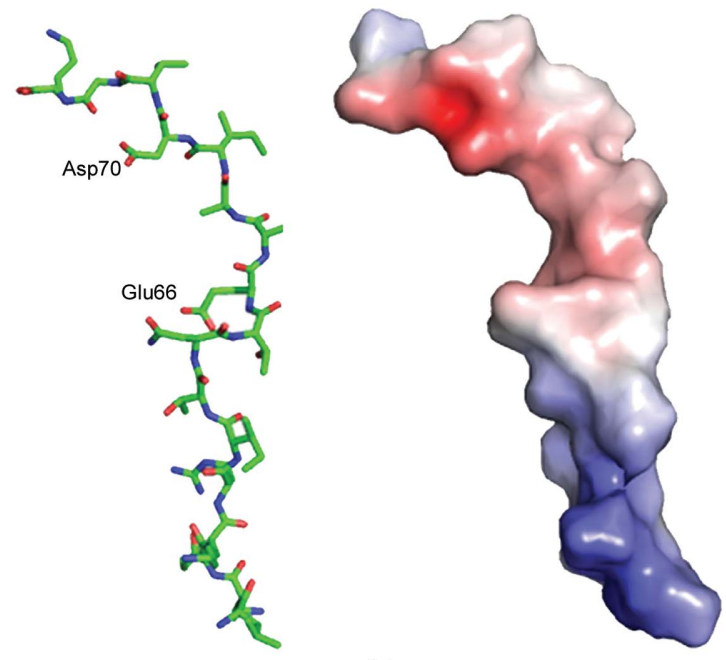

(c)

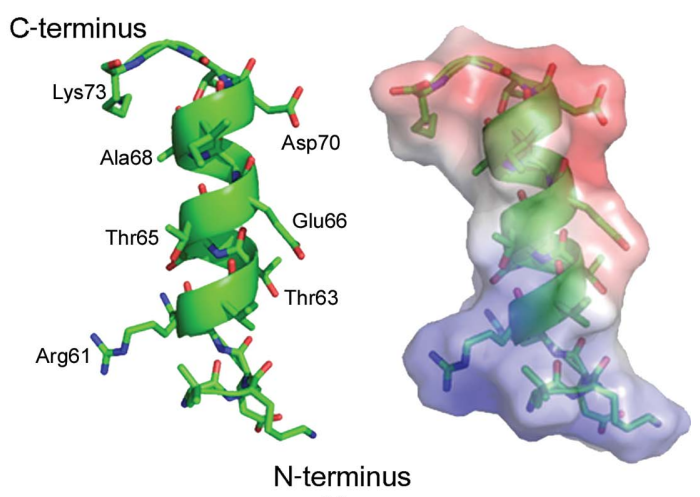

(d)

Figure 1

MC R354 structure. (a) In the structure of the asymmetric unit, MBP (cyan and green) and the MIC (blue) are presented as ribbons and the maltose molecule (magenta) is presented as sticks. $(b) 2 F_{\mathrm{o}}-F_{\mathrm{c}}$ electron density (at the $1 \sigma$ level) around MamC-MIC presented as sticks. MBP is presented as a ribbon (cyan), whereas symmetry-related molecules are in grey. (c) MC R354 (PDB entry 5mm3) shown as sticks (left) and as an electrostatic surface representation (right; blue for positive charges and red for negative charges). (d) MamC-MIC (PDB entry 5e7u) presented as ribbons and sticks. An electrostatic surface representation is shown on the right (blue for positive charges and red for negative charges). 
$2.52 \mathrm{~nm}$. MC R354 presents a higher $R_{\mathrm{g}}$ than MBP-MamCMIC, namely $2.83 \mathrm{~nm}$ and $2.71 \pm 0.01 \mathrm{~nm}$, respectively (Fig. 2c). These results support our assumption that MC R354 has a long unstructured tail in solution, similar to the unstructured tail that exists in the protein crystal form.

Of the two other constructs of MamC-MIC, only MC K170 produced a measurable crystal. The crystals had the shape of small rods, differing from the MC R354 crystals. The MC K170 crystals diffracted to $2.3 \AA$ resolution. Similar to MC R354, molecular replacement was performed via the MBP-MamCMIC structure followed by manual building of MamC-MIC.

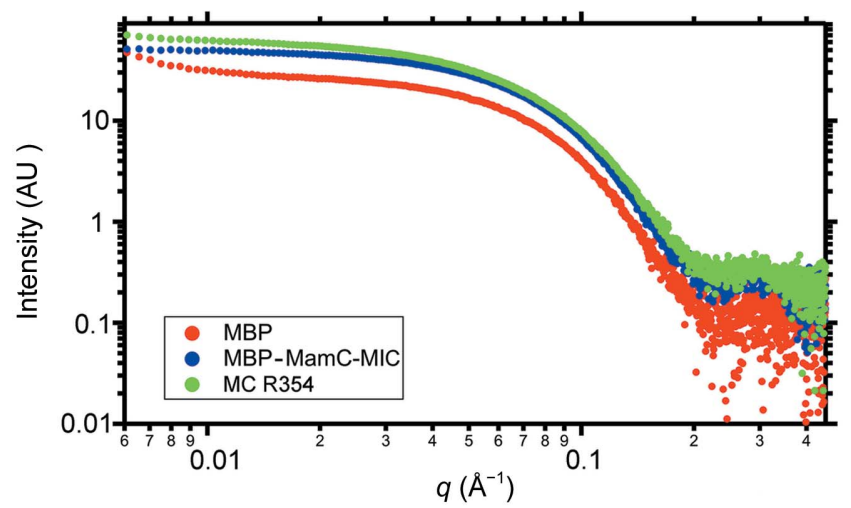

(a)

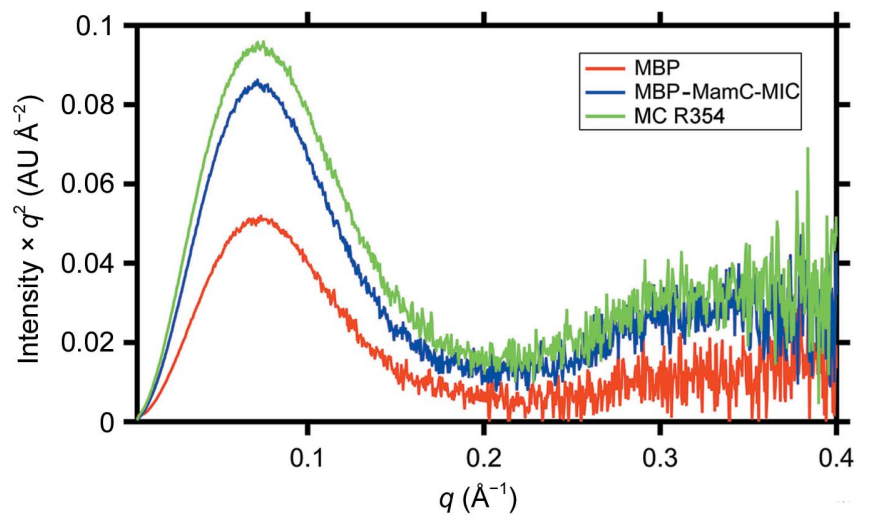

(b)

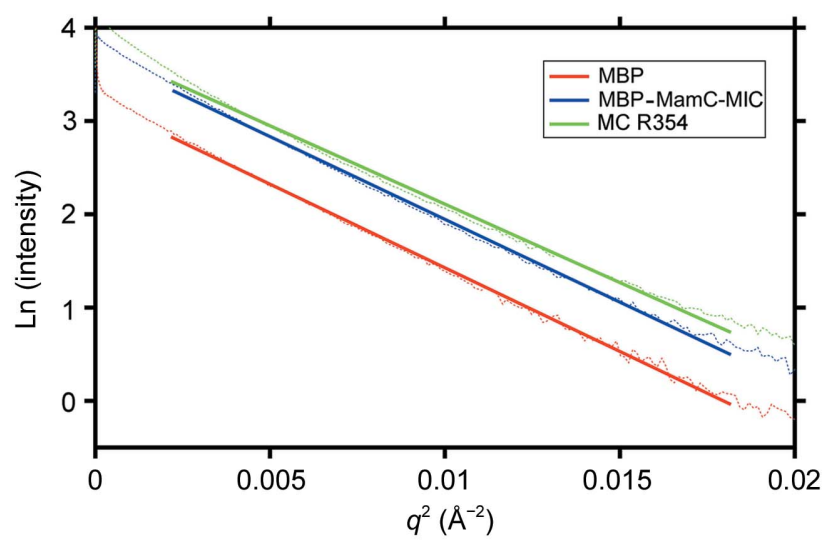

Figure 2

(c)

SAXS analysis. (a) One-dimensional plot of the scattering data for MBP (red), MBP-MamC-MIC (blue) and MC R354 (green) at $2 \mathrm{mg} \mathrm{ml}^{-1}$. (b) A Kratky plot for all three proteins. (c) A Guinier plot of the data yielded different $R_{\mathrm{g}}$ values for each protein $\left(\mathrm{MBP}, R_{\mathrm{g}}=2.52 \mathrm{~nm}\right.$; MBP_MamC_MIC, $\left.R_{\mathrm{g}}=2.71 \mathrm{~nm} ; \mathrm{MC} \mathrm{R} 354, R_{\mathrm{g}}=2.83 \mathrm{~nm}\right)$.
This structure contains four monomers in the asymmetric unit and we can detect full-length MamC-MIC in three of the four monomers in the asymmetric unit (Fig. 3a; PDB entry 6eqz). In the fourth monomer (chain $G$ ) only Asp70 could not be detected in the MamC-MIC structure, which might indicate loop flexibility. The MamC-MIC structure in MC K170 is similar to a $\beta$-hairpin fold and does not adopt a helical structure. Overlapping the monomers in the asymmetric unit

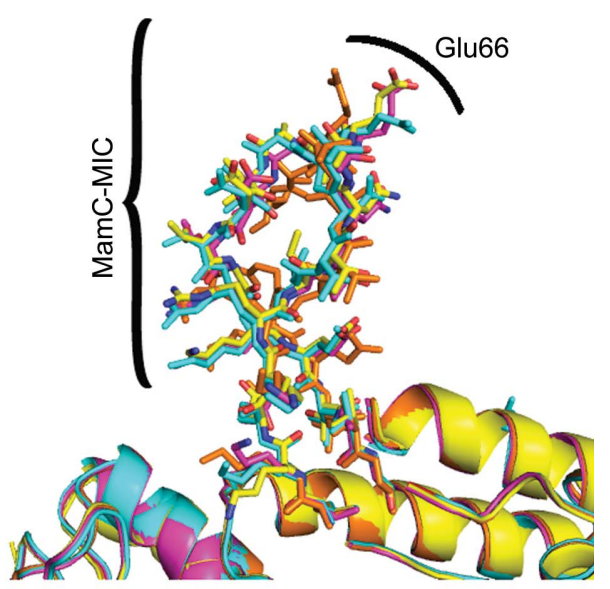

(a)

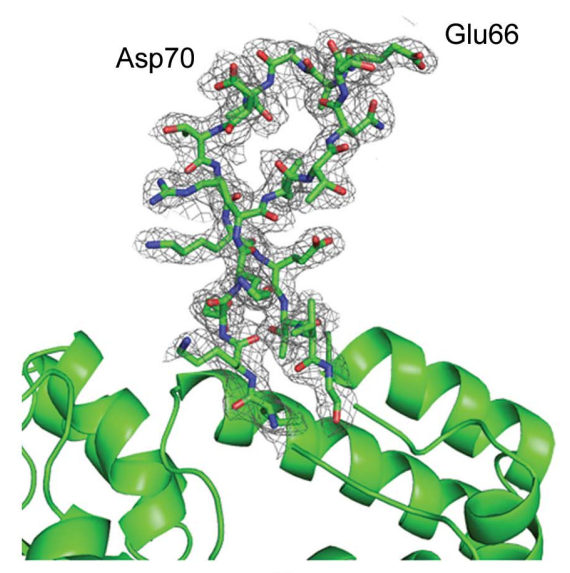

(b)

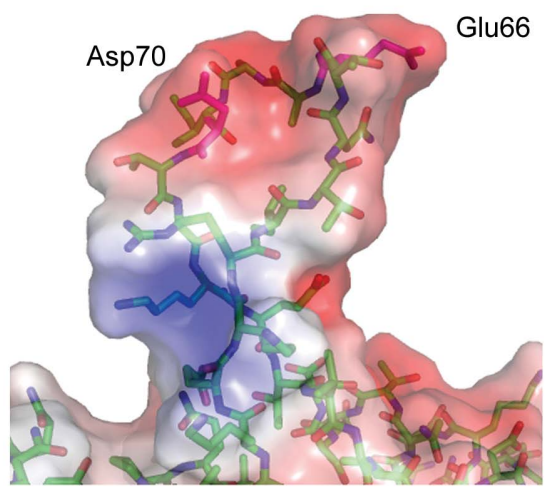

(c)

Figure 3

MC K170 structure. (a) Overlapping MamC-MIC molecules from the four asymmetric units are presented as ribbons and sticks. (b) $2 F_{\mathrm{o}}-F_{\mathrm{c}}$ electron density (at the $1 \sigma$ level) around MamC-MIC presented as sticks. MBP is presented as a ribbon (green). (c) Electrostatic density map around MamC-MIC in the MC K170 structure (blue for positive charges and red for negative charges). 
revealed an r.m.s.d. of $0.33 \AA$. The major differences between the chains are in the MamC-MIC orientation and not between the MBP structures (Figs. $3 a$ and $3 b$ ). The $\beta$-hairpin-like fold is similar in all the monomers, but there are small shifts in the

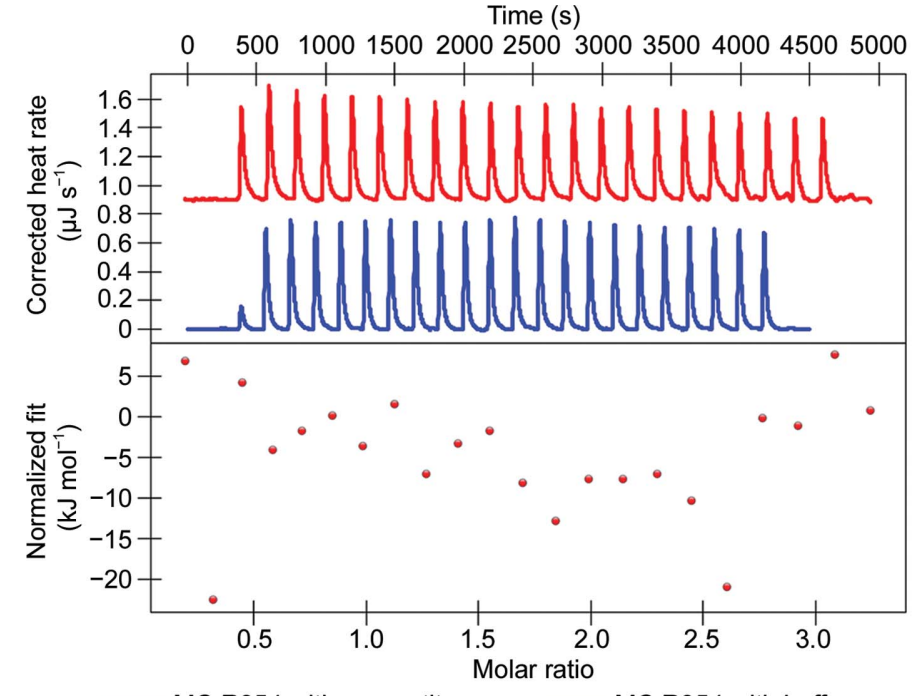

(a)

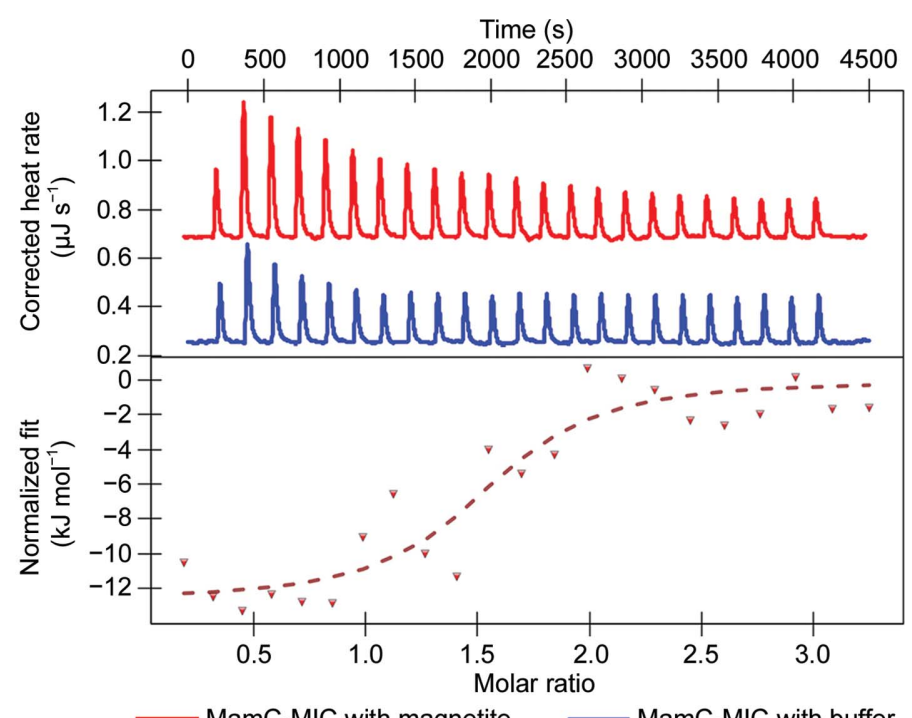

(b)

Figure 4

ITC measurements of protein-magnetite nanoparticle interactions. (a) Top: heat-flow graph for each injection as a function of time for MC R354 with magnetite (red); the blue plot is for protein injection into a buffer. Bottom: heat-rate normalization graph for each injection with the injected mole number for the interaction of MC R354 with magnetite particles $(0.019 \mathrm{mM})$. (b) Top: heat-flow graph for each injection as a function of time for MBPMamC-MIC with magnetite (red); the blue plot represents protein injected into buffer. The heat of dilution of both proteins into the buffer was subtracted. Bottom: heat-rate normalization graph for each injection with the injected mole number for the interaction of MBP-MamC-MIC with magnetite particles $(0.019 \mathrm{~m} M)$.

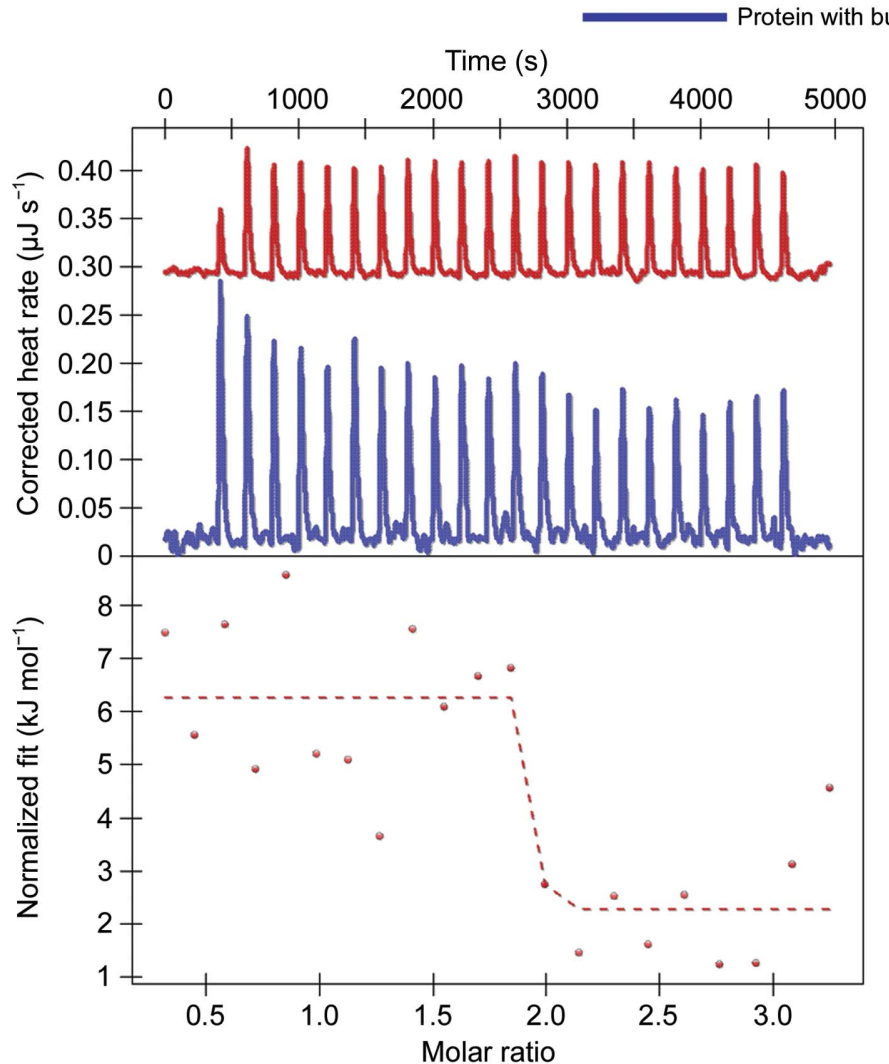

(a)

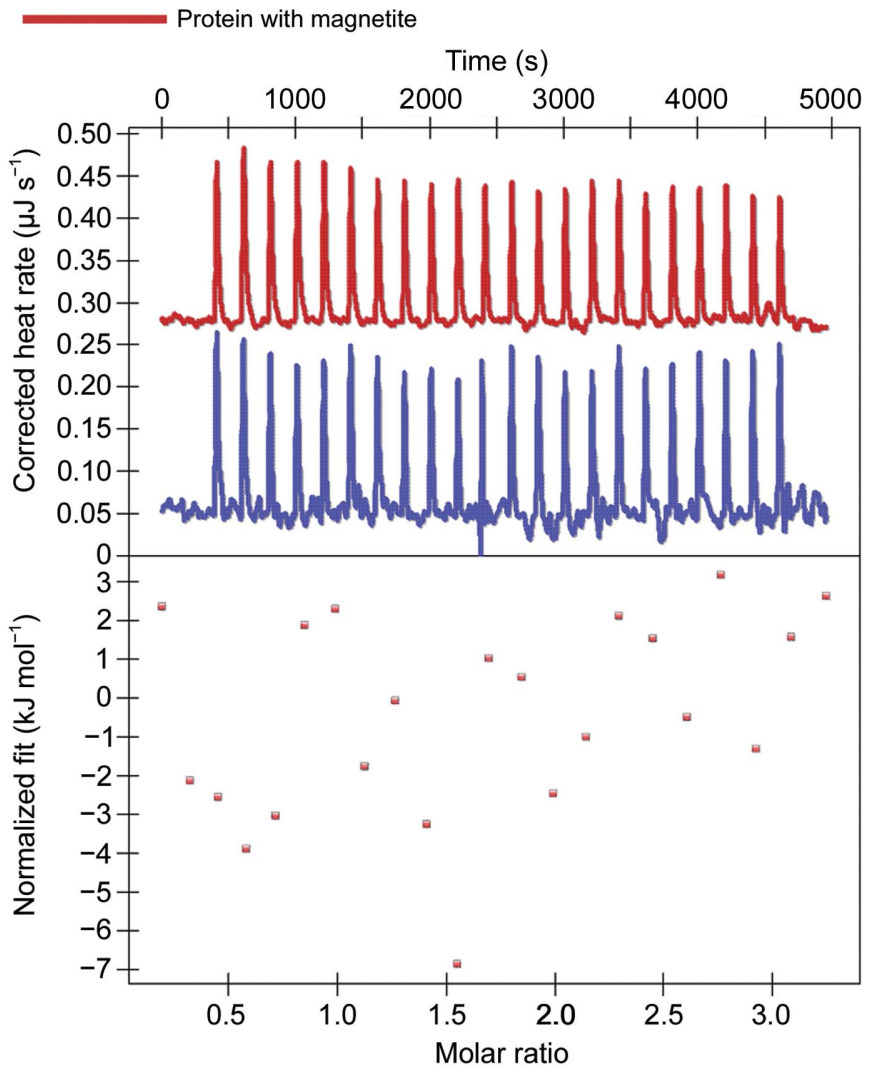

(b)

Figure 5

ITC measurements of protein-magnetite nanoparticle interactions. Each sample is described by a heat-flow graph (top) and a heat-rate normalization graph (bottom). Sample injection into the magnetite sample $(0.0190 \mathrm{mM})$ is in red and protein-sample injection into a buffer is in blue. (a) MamC K313, (b) MamC K170. 
MamC-MIC orientation. According to the electrostatic density map, the surface of the $\beta$-turn is negatively charged, which differs from the charge in the MC R354 MamC-MIC (Fig. 3c). Although the charge is negative, Glu66 and Asp70, which are already known to be essential for MamC-MIC function, point in different directions (Fig. 3c). In the SAXS measurements the two proteins presented $R_{\mathrm{g}}$ values that were similar to or higher than that detected for MC R354 (data not shown). MC K170 had an $R_{\mathrm{g}}$ value of $2.86 \pm 0.18 \mathrm{~nm}$, while MC K313 had an $R_{\mathrm{g}}$ value of $2.81 \pm 0.25 \mathrm{~nm}$. Both constructs generated a curve indicative of a monomeric state and a globular protein (data not shown). Calculation of the theoretical $R_{\mathrm{g}}$ from the atomic structures shows minor differences between each of the MamC-MIC constructs. The MBP structure (PDB entry 3puz; Oldham \& Chen, 2011) revealed an $R_{\mathrm{g}}$ of $21.79 \AA$, which was lower than those of the other MamCMIC structures. While MBP-MamC-MIC (PDB entry 5e7u) showed an $R_{\mathrm{g}}$ of $22.12 \AA$, MC R354 and MC K170 showed higher $R_{\mathrm{g}}$ values of 22.58 and $22.41 \AA$, respectively. These SAXS results, the theoretical $R_{\mathrm{g}}$ and the MamC-MIC crystal structures may indicate flexibility of the MIC, with all of the MamC constructs being associated with higher $R_{\mathrm{g}}$ values than that of MBP alone.

\subsection{Protein-mineral interactions}

Despite our initial assumption that MC R354 interacts with magnetite particles, the ITC results showed that it did not, as opposed to previous results obtained with the MBP-MamCMIC construct (Figs. $4 a$ and $4 b$ ). This is surprising as MC R354 has the same exposed MamC-MIC sequence as MBP-MamCMIC, albeit with a different structure. The lack of magnetite binding by the newer construct could be related to differences in the loop structure or orientation which could prevent protein-magnetite interactions. This hypothesis is supported by our previous results, in which a short fragment from MamC-MIC (Arg61-Gly77) did not interact with magnetite particles, most likely owing to the lack of a defined MIC structure (Nudelman et al., 2016). This result is in agreement with the conclusion that MamC must be well structured in order to play a role in magnetite growth, as reflected by effects on the size of the crystals (Lopez-Moreno et al., 2017).

Still, factors other than the structure must be taken into account in order to explain the interaction of these proteins with magnetite crystals. For instance, in the numerous failed attempts to crystallize Mms6-MIC, the protein probably displayed an unstructured tail yet maintained the ability to interact with magnetite particles (Nudelman et al., 2016).

Not only the number of acidic amino acids but also the orientation of these acidic amino acids (stereochemical recognition) must be correct to allow the interaction of the MIC with magnetite. ITC analysis showed that even though MC K170 has the same number of acidic amino acids as MC $\mathrm{R} 354$, it does not interact with magnetite particles. Accordingly, MC K313 has a weak endothermic interaction that

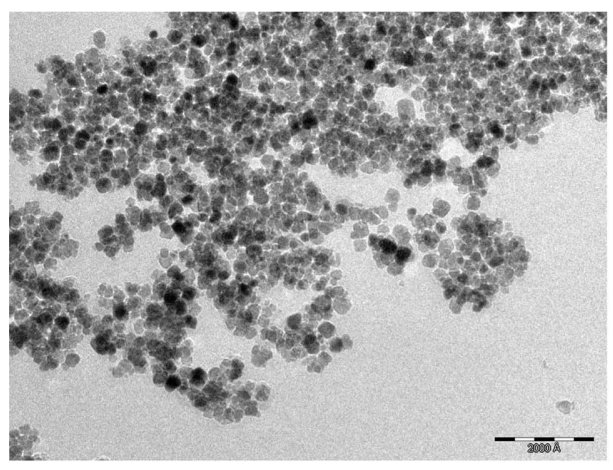

(a)

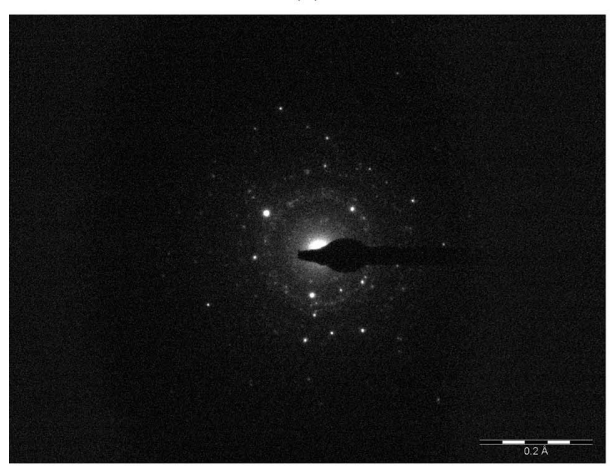

(b)

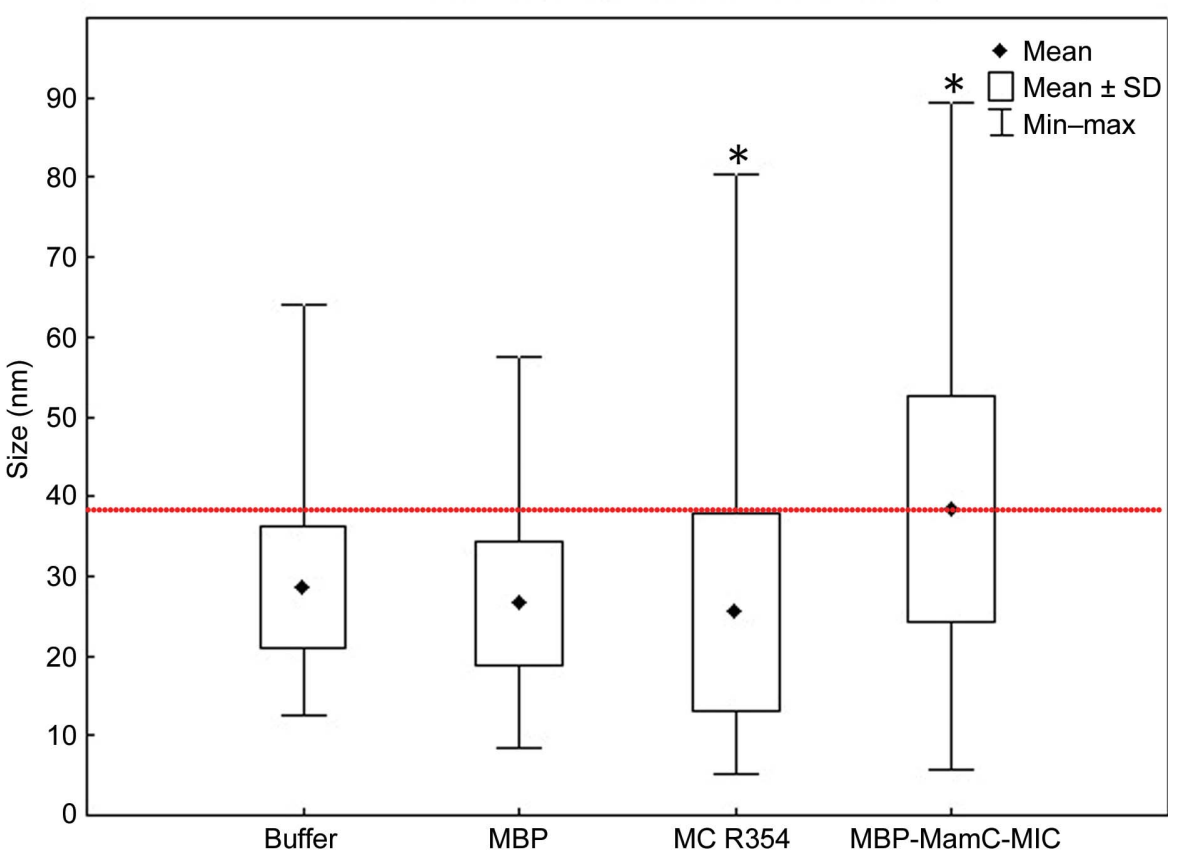

(c)

Figure 6

In vitro MC R354 iron-precipitation assay. (a) Magnetic particles prepared in vitro by magnetite precipitation with MBP-MamC-MIC, MC R354 and buffer. Scale bars represent $200 \mathrm{~nm}$. The protein concentration was $10 \mu \mathrm{g} \mathrm{ml}^{-1}$. (b) Selected-area electron diffraction (SAED) of the crystals shown in (a). (c) Size distribution of magnetite particles prepared with different proteins at a concentration of $10 \mu \mathrm{g} \mathrm{ml} \mathrm{l}^{-1}$ or in a protein-free experiment. The red line refers to the maximum size achieved by $90 \%$ of the particle population in the control experiment. The statistical significance of differences from MBP-MamC-MIC was tested using an ANOVA test $\left(P<6.43 \times 10^{-32}\right)$. 
differs from the exothermic interaction shown by MamC-MIC, as presented in our previous study (Fig. 5; Nudelman et al., 2016). The lack of stereochemical recognition in these constructs, compared with that of MamC-MIC, may explain the differences observed. According to structural predictions, the Mms6 peptide is only attached at its $\mathrm{N}$-terminus, while the C-terminal end is highly flexible without any defined structure (Nudelman \& Zarivach, 2014). It is important to say that the ITC results point to weak interactions that differ from the interaction of helical MamC and MBP with a C-terminally placed Mms6, which was used as a positive control.

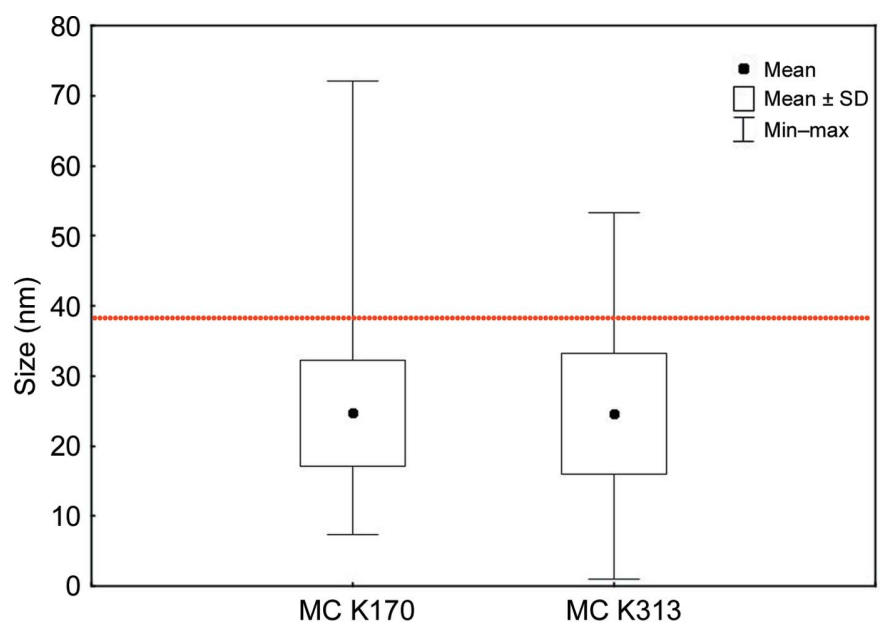

(a)
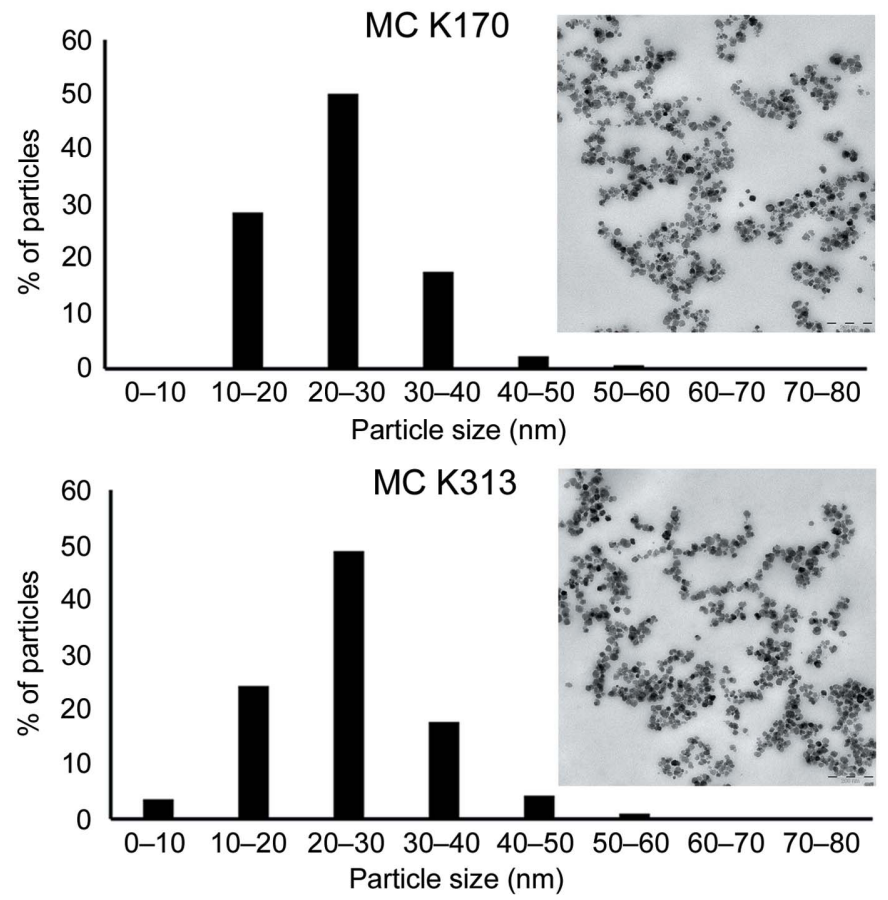

(b)

Figure 7

In vitro iron co-precipitation assay. (a) Size distribution of magnetite particles obtained with different proteins at a concentration of $10 \mu \mathrm{g} \mathrm{ml}^{-1}$ or in a protein-free experiment. The red line refers to the maximum size achieved by $90 \%$ of the particle population in the control experiment. (b) Magnetic particles prepared in vitro by magnetite precipitation with MC K313 and MC K170. Scale bars represent $200 \mathrm{~nm}$ and a histogram analysis is shown for each sample.

\subsection{In vitro iron co-precipitation}

One important role that MamC plays in magnetosome formation is to affect magnetite size and shape during the biomineralization process. Therefore, in the present study we performed in vitro iron-precipitation assays to determine whether MC R354 also had an effect on magnetite size and shape. The average magnetite particle size obtained in the presence of MC R354 was $25.43 \pm 0.57 \mathrm{~nm}$, while that for MBP-MamC-MIC was $38.35 \pm 0.93 \mathrm{~nm}$ (Fig. 6; Nudelman et al., 2016). An ANOVA test showed a small $P$ value of $6.43 \times$ $10^{-32}$, with an $F$ value of 152.96 . A low $P$-value and an $F$ value greater than 1 mean that the two populations are significantly different. Moreover, the crystals formed in the presence of MC R354 displayed less defined faces than those observed in crystals formed in the presence of MBP-MamC-MIC (Fig. 6). The differences between these two populations cannot be explained by the presence of MBP, since the ANOVA test showed no significant differences $(P$-value $=0.07)$ between the size of the particles obtained in the presence of MC R354 and those obtained in the presence of MBP (average size of $26.61 \mathrm{~nm})$.

MC K170 and MC K313 were also tested in order to check their effect on magnetite synthesis in vitro. The presence of the MamC constructs MC K170 and MC K313 revealed magnetite particles of similar average size ( $24.7 \mathrm{~nm}$; Fig. 7), values that were similar to those obtained in the presence of MC R354. In particular, MamC constructs produce particles with a similar size distribution, in which $50 \%$ were of a size between 20 and $30 \mathrm{~nm}$. Since it has been demonstrated that MamC-MIC only functions when folded as a helix, the similar sizes that were formed using all MamC constructs may also indicate a lack of structure in each case (Fig. 7).

\section{Conclusions}

Our results emphasize the previous results that MamC controls magnetite crystal shape and size during magnetosome formation (Nudelman et al., 2016; Valverde-Tercedor et al., 2015). However, these results provide new insight that points to MamC as not only offering high saturation areas for magnetite nucleation but also a template for magnetite growth. In fact, the lack of structure leads to a failure to interact with magnetite and to control crystal size and probably shape. We demonstrated that MamC-MIC must form a helical structure in order to interact with magnetite planes and control crystal shape and size. In our previous work, we showed that there are two amino acids in MamC-MIC that are highly important for function: Glu66 and Asp70. The distance between them when MamC-MIC assumes a helical structure fits the distance between two $\mathrm{Fe}$ atoms on the magnetite surface, which enables MIC-magnetite interaction. In contrast, the MIC in MC R354 is highly flexible, without any defined shape, making it difficult for the MIC to interact with the mineral planes. Moreover, MC K170 does not show any ability to interact with magnetite particles, although the MIC has a $\beta$-hairpin-like shape in the MC K170 structure and a negative charge on its surface. Still, the distance between 
Glu66 and Asp70 is too long in order for it to interact directly with the particle surface. Our assumption is that MamC-MIC adopts a $\alpha$-helical structure owing to its location between two transmembrane helices. This helix can act as an anchor to the magnetosome membrane and as a protein-oligomerization module within the membrane. Our findings further indicate that although the MIC contains the necessary sequence for magnetite binding in an exposed form, its structure plays a crucial role in successful binding. Furthermore, the results support the MamC-mineral interaction model for describing helix-magnetite interactions.

\section{Acknowledgements}

We thank Dr Anat Shahar from the Macromolecular Crystallography Research Center (MCRC) for her help with the $\mathrm{X}$-ray crystallography analyses. The crystallography experiments were performed on beamlines ID14-4 and ID29 at the European Synchrotron Radiation Facility (ESRF), Grenoble, France. We are grateful to the Local Contact at the ESRF for providing assistance in using beamlines ID14-4 and ID29.

\section{Funding information}

This work is supported by the Israel Science Foundation, the Israel Ministry of Science, Technology and Space, the European Molecular Biology Organization, the Max Planck Society and CMST COST Action CM0902. CJL thanks projects CGL2013-46612 and CGL2016-76723 from the Ministerio de Economía y Competitividad, Spain and Fondo Europeo de Desarrollo Regional (FEDER). DF acknowledges financial support from the Max Planck Society.

\section{References}

Addadi, L. \& Weiner, S. (1992). Angew. Chem. Int. Ed. Engl. 31, 153169.

Amemiya, Y., Arakaki, A., Staniland, S. S., Tanaka, T. \& Matsunaga, T. (2007). Biomaterials, 28, 5381-5389.

Baumgartner, J., Bertinetti, L., Widdrat, M., Hirt, A. M. \& Faivre, D. (2013). PLoS One, 8, e57070.

DeLano, W. (2002). CCP4 Newsl. Protein Crystallogr. 40, contribution 11. http://www.ccp4.ac.uk/newsletters/newsletter40/ 11_pymol.pdf.

Dove, P. M. (2010). Elements, 6, 37-42.

Emsley, P. \& Cowtan, K. (2004). Acta Cryst. D60, 2126-2132.

Fisher, L. W., Torchia, D. A., Fohr, B., Young, M. F. \& Fedarko, N. S. (2001). Biochem. Biophys. Res. Commun. 280, 460-465.

Franke, D., Petoukhov, M. V., Konarev, P. V., Panjkovich, A., Tuukkanen, A., Mertens, H. D. T., Kikhney, A. G., Hajizadeh, N. R., Franklin, J. M., Jeffries, C. M. \& Svergun, D. I. (2017). J. Appl. Cryst. 50, 1212-1225.

Grünberg, K., Müller, E. C., Otto, A., Reszka, R., Linder, D., Kube,
M., Reinhardt, R. \& Schüler, D. (2004). Appl. Environ. Microbiol. 70, 1040-1050.

Jelesarov, I. \& Bosshard, H. R. (1999). J. Mol. Recognit. 12, 3-18.

Jogler, C. \& Schüler, D. (2009). Annu. Rev. Microbiol. 63, 501-521.

Joosten, R. P. et al. (2009). J. Appl. Cryst. 42, 376-384.

Kabsch, W. (2010). Acta Cryst. D66, 125-132.

Kashyap, S., Woehl, T. J., Liu, X., Mallapragada, S. K. \& Prozorov, T. (2014). ACS Nano, 8, 9097-9106.

Lopez-Moreno, R., Fernández-Vivas, A., Valverde-Tercedor, C., Azuaga Fortes, A. I., Casares Atienza, S., Rodriguez-Navarro, A. B., Zarivach, R. \& Jimenez-Lopez, C. (2017). Cryst. Growth Des. 17, 1620-1629.

Lowenstam, H. A. \& Weiner, S. (1989). On Biomineralization. Oxford University Press.

Mann, S. (2001). Biomineralization: Principles and Concepts in Bioinorganic Materials Chemistry. Oxford University Press.

McCoy, A. J., Grosse-Kunstleve, R. W., Adams, P. D., Winn, M. D., Storoni, L. C. \& Read, R. J. (2007). J. Appl. Cryst. 40, 658-674.

Murshudov, G. N., Skubák, P., Lebedev, A. A., Pannu, N. S., Steiner, R. A., Nicholls, R. A., Winn, M. D., Long, F. \& Vagin, A. A. (2011). Acta Cryst. D67, 355-367.

Nudelman, H., Valverde-Tercedor, C., Kolusheva, S., Perez, T., Widdrat, M., Grimberg, N., Levi, H., Nelkenbaum, O., Davidov, G., Faivre, D., Jimenez-Lopez, C. \& Zarivach, R. (2016). J. Struct. Biol. 194, 244-252.

Nudelman, H. \& Zarivach, R. (2014). Front. Microbiol. 5, 9.

Oldham, M. L. \& Chen, J. (2011). Science, 332, 1202-1205.

Otwinowski, Z. \& Minor, W. (1997). Methods Enzymol. 276, 307-326.

Perez Gonzalez, T., Rodriguez-Navarro, A. B. \& Jiminez-Lopez, C. (2011). J. Supercond. Nov. Magn. 24, 549-557.

Raschdorf, O., Bonn, F., Zeytuni, N., Zarivach, R., Becher, D. \& Schüler, D. (2017). J. Proteomics, https://doi.org/10.1016/ j.jprot.2017.10.007.

Rawlings, A. E., Bramble, J. P., Hounslow, A. M., Williamson, M. P., Monnington, A. E., Cooke, D. J. \& Staniland, S. S. (2016). Chemistry, 22, 7885-7894.

Tanaka, M., Mazuyama, E., Arakaki, A. \& Matsunaga, T. (2011). J. Biol. Chem. 286, 6386-6392.

Valverde-Tercedor, C., Montalbán-López, M., Perez-Gonzalez, T., Sanchez-Quesada, M. S., Prozorov, T., Pineda-Molina, E., Fernandez-Vivas, M. A., Rodriguez-Navarro, A. B., Trubitsyn, D., Bazylinski, D. A. \& Jimenez-Lopez, C. (2015). Appl. Microbiol. Biotechnol. 99, 5109-5121.

Wald, T., Osickova, A., Sulc, M., Benada, O., Semeradtova, A., Rezabkova, L., Veverka, V., Bednarova, L., Maly, J., Macek, P., Sebo, P., Slaby, I., Vondrasek, J. \& Osicka, R. (2013). J. Biol. Chem. 288, 22333-22345.

Widdrat, M., Kumari, M., Tompa, É., Pósfai, M., Hirt, A. M. \& Faivre, D. (2014). ChemPlusChem, 79, 1225-1233.

Wojtas, M., Dobryszycki, P. \& Ożyhar, A. (2012). Advanced Topics in Biomineralization, edited by J. Seto, pp. 1-32. Rijeka: Intech. https://doi.org/10.5772/31121.

Yamagishi, A., Narumiya, K., Tanaka, M., Matsunaga, T. \& Arakaki, A. (2016). Sci. Rep. 6, 35670.

Zwart, P. H., Afonine, P. V., Grosse-Kunstleve, R. W., Hung, L.-W., Ioerger, T. R., McCoy, A. J., McKee, E., Moriarty, N. W., Read, R. J., Sacchettini, J. C., Sauter, N. K., Storoni, L. C., Terwilliger, T. C. \& Adams, P. D. (2008). Methods Mol. Biol. 426, 419-435. 